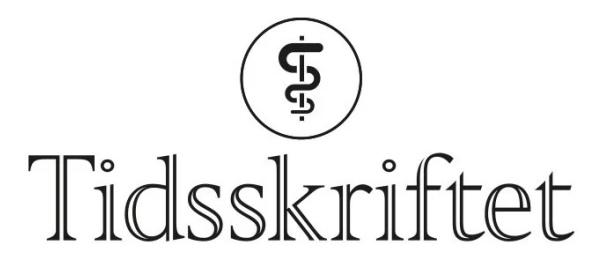

DEN NORSKE LEGEFORENING

\title{
Nesten fullkommen infeksjonsinnføring
}

\section{ANMELDELSER}

\section{JON BIRGER HAUG}

Medisinsk klinikk

Aker universitetssykehus

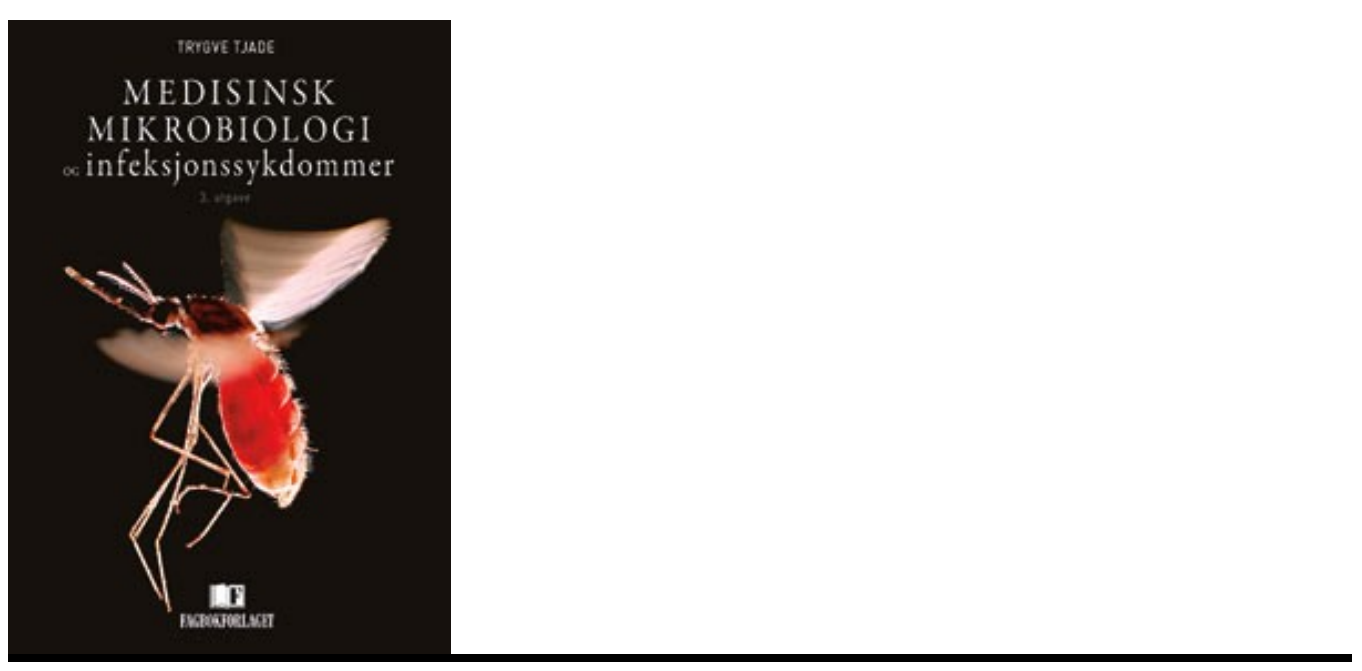

Tjade, T.

Medisinsk mikrobiologi og infeksjonssykdommer

3. utg. 316 s, tab, ill. Bergen: Fagbokforlaget, 2008. Pris NOK 398

ISBN 978-82-450-0736-7

Store fagområder søkes dekket på knapt 400 sider i 3 . utgave av denne læreboken i medisinsk mikrobiologi og infeksjonssykdommer. Forfatteren har lang erfaring i undervisning av ulike helsepersonellgrupper, og boken er beregnet på dem alle, fra legestudenter til aktører innen alternativ medisin. Den introduseres som en kortfattet innføring for førstnevnte og en basisbok for de øvrige personellgruppene. Med en så bred leserkrets og ofte nokså resistent fagstoff er dette et ambisiøst prosjekt. Har man lyktes? 
Etter de fleste kriterier er svaret ja, og på forbilledlig vis. Anmelder husker sin «kurzgefasste Einleitung» i mikrobiologi fra 1970-årenes tyske mikrobiologiundervisning og tenker at verden tross alt er gått fremover. En fagbok kan vel neppe gis karakteristikker som «pageturner» eller «neglebitende», men denne er svært lesbar og velskreven. Forlaget har påspandert en delikat innbinding av høy kvalitet, og innholdet kommer godt frem med logisk oppbygning av kapitler, margstikkord, høy kvalitet på de mange og gode illustrasjonene og fremfor alt en layout som gjør boken til en nytelse å bla i. Hvert kapittel innledes med en 'etter-å-ha-lest-dette-skal-du-vite-at'-boks og avslutter med kontrollspørsmål. Der forfatteren velger å gå mer i dybden, er dette gjort i egne avsnitt med mindre skrifttyper. Ordforklaringer og stikkordsregister virker gjennomarbeidet og komplett. Fremfor alt finnes massevis av historiske og dagsaktuelle anekdoter, som spenner fra Semmelweiss til salmonellautbrudd på Jeløya.

Totalt sett er boken et fremskritt i forhold til hva som utgis på fagfeltet. Forsiktige innvendinger er at prosjektet med fordel kunne ha vært utvidet i forhold til smittevern og infeksjonsmedisin. På disse feltene er boken noe usystematisk. Klinisk antibiotikabruk er kun sporadisk omtalt og det fokuseres mye på resistensutvikling. I tillegg er det ganske minimalt om emnet smittevern.

Men: løp og kjøp! Dette er en av de beste bøkene jeg har sett som basisinnføring og appetittvekker. Så medisinstudenter, dere som likevel ikke kommer unna Det Kjedelige: les i tillegg også tradisjonelt stoff - og pugg - som generasjoner før dere. For vårt smittevernpersonell: Skriv noe eget - det mangler fortsatt i Norge.

Publisert: 15. januar 2009. Tidsskr Nor Legeforen. DOI:10.4045/tidsskr.08.0500

(C) Tidsskrift for Den norske legeforening 2023. Lastet ned fra tidsskriftet.no 26. april 2023. 